\title{
Does Foreign Direct InVEstMent DeCREASE CORRUPTION?*
}

\author{
Felipe LarRaín B. \\ Pontificia Universidad Católica de Chile \\ José TAVARES \\ Universidade Nova, Portugal
}

\begin{abstract}
This paper assesses the effect of openness on corruption, using foreign direct investment (FDI) inflows as a measure of openness, after trade intensity is accounted for. We use a broad cross section of countries over the period 1970 to 1994 and address the issue of causality with a new set of instrumental variables relying on geographical and cultural distance between the FDI exporting and recipient countries. The economics literature has demonstrated that higher corruption levels discourage FDI. Here we study the reverse link, that is, how foreign direct investment impacts corruption. We find that FDI as a share of GDP is significantly associated with lower corruption levels, irrespective of import intensity levels. The quantitative impact of FDI on corruption appears to be of the same order of magnitude as that of per capita GDP.
\end{abstract}

JEL: F10, F13, F30, H10.

Keywords: Foreign Direct Investment, Corruption, International Trade, Instrumental Variables.

\section{INTRODUCTION}

In recent years researchers have presented new results on the consequences and determinants of corruption. High levels of corruption have been associated

* We have benefited from valuable comments by Oriana Bandera, Marco Celentani, Gerardo Esquivel, Rafael DiTella, George Siotis, Raimundo Soto, and two anomymous referees as well as participants in the NEUDC Conference at Harvard University, the LACEA Conference, and seminars at Universidad Carlos III, Universidade Nova de Lisboa and ISEG. Rafael LaPorta and Francis $\mathrm{Ng}$ have generously provided access to their data. Andrea Cid, Lorena Barberia and Claudio Sauer provided excellent research assistance. Felipe Larraín thanks financial support from Chile's Fondo de Ciencia y Tecnología (FONDECYT) project 1030950; Jose Tavares from Fundação para a Ciência e Tecnologia and POCTI through FEDER. All errors remain our responsibility. 
with low exposure to international trade, high tariff levels and dependence on natural resources, ${ }^{1}$ while corruption itself tends to slow economic growth and discourage investment. ${ }^{2}$ In spite of substantial empirical work on the relationship between trade and corruption, there is no systematic study of the effect of foreign direct investment inflows (FDI) on corruption. ${ }^{3}$

In this paper we estimate the impact of FDI inflows on corruption at the country level, taking into account the issue of reverse causation. The paper adds to the current literature in three ways: first, it develops new instruments for the degree of country openness to FDI and trade, relying on a country's geographical and cultural proximity to the major world economies, and on outflows from the latter; second, it uses a large cross-country data set; third, it estimates the effect of FDI on corruption after the role of trade openness is accounted for. Given the high correlation between the levels of openness to trade and to FDI, it is key to take both indicators into consideration.

The paper is organized as follows. Section 2 reviews the theoretical and empirical literature associating foreign direct investment and corruption. Section 3 presents the data, the specification and the empirical results; Section 4 concludes.

\section{Foreign Direct Investment and Corruption}

A closed economy is an important source of rents. In the trade area, the existence of different duties (and exceptions) gives public officials substantial discretion and provides fertile ground for political influence while free trade leaves little or no room for policymaker discretion. ${ }^{4}$ Several studies have documented the empirical link between trade openness and corruption ${ }^{5}$ but the association between foreign investment and corruption is largely neglected.

${ }^{1}$ See Ades and DiTella (1999), Gatti (2000), and Leite and Weidmann (1999)..

2 See Mauro (1995) for evidence that both economic growth and private investment are negatively affected by the extent of corruption and Wei (2000a) for estimates of the impact of corruption on FDI.

${ }^{3}$ While research by Wei $(1997,2000$ a) has estimated whether and how much corruption deters FDI, but the reverse relationship is at least as important and heretofore an open issue.

${ }^{4}$ Several theoretical efforts have been undertaken to understand the influence of domestic political actors on trade policies. Krueger (1974) developed a theoretical model focusing on trade-restrictions as originators of rents and an inducement to corruption. In her model, corruption results from competition for import licenses that give access to low cost imports. Bhagwati and Srinivasan (1980) analyze the case where agents attempt to appropriate a share of the tariff revenue resulting from the adoption of protectionist policies. Brock and Magee (1978) pioneered the theoretical analysis of lobbies seeking the imposition of protectionist tariffs. More recently, Helpman (1997) has emphasized the importance of two-way interactions between trade policy choices and domestic special interest groups.

${ }^{5}$ Ades and DiTella (1999) have examined the effect of rents on corruption to conclude that corruption increases in countries where local companies are able to isolate themselves from foreign competition. These authors use the share of imports in GDP as an indicator of rents available in the economy and find that an increase in international trade exposure decreases the 
However, foreign direct investment projects have elements of a "hostage relationship" whereby public officials can collect bribes before and after the investment is actually undertaken since different discretionary public decisions -from sectoral regulation to infrastructure provision- have a direct impact on project profitability. Foreign direct investment is particularly vulnerable to corrupt activities for other reasons: the incentive to corrupt is higher due to income differentials, that is, a small bribe from the point of view of the investor firm goes a long way in terms of real value to the local public official; in lax regulatory frameworks foreign investors can trade bribes for market power in the local economy and recover that cost later through higher prices; foreign direct investment is often associated with large infrastructure projects and privatization programs so that the size of the economic rents involved is considerable. ${ }^{6}$ Several elements concur to facilitate the emergence of corruption associated with FDI projects: market power, discretionary decision-making and imperfectly accountable public officials.

On the other hand, foreign direct investment may decrease corruption as the high levels of international capital mobility make foreign investors more likely to exit the market if corrupt behavior is not kept in check. Wei (2000a) has found evidence that American and European investors are indeed averse to corruption in the host countries. Second, as Kimberley (1997) suggests, and given the importance of foreign investment to local economies, foreign standards of probity have an impact on local officials and their behavior. ${ }^{7}$ Thirdly, as put forward by RoseAckerman (1975), corruption may be less frequent if it has long-term negative consequences to the firms and individuals involved, as is the case with FDI projects. In addition, as reported in Tanzi and Davoodi (1997), until a few years ago some investor countries considered legal and tax deductible the commissions paid to foreign officials. More recently, however, the OECD has moved to criminalize "commissions" to foreign officials, in recognition of the connection between foreign direct investment and corruption.

level of corruption. The authors also use distance to trading partners as a measure of exogenous exposure to competition from foreign firms and find that higher distances lead to more corruption. Wei (2000b) constructs an indicator of "natural openness" using bilateral distance, remoteness, country size and common language to find that more open countries are also less corrupt.

6 Tanzi and Davoodi (1997) present strong results of a positive association between corruption levels and the provision of infrastructure. These authors show that, whereas the amount of public investment increases with corruption, indicators of quality deteriorate. Shleifer and Vishny (1993) suggest that large-size projects offer more opportunities for corruption, especially if their value is difficult to monitor. This is consistent with the fact that education, unlike public investment, is under-financed in more corrupt countries, as reported in Mauro (1998); the true cost of a dam is harder to assess than the cost of textbooks.

${ }^{7}$ According to Hines (1995), U.S. multinationals routine engagement in bribery changed since 1977, when a U.S. law criminalized the corruption of foreign officials. Using various controls to estimate the effect of the anti-bribery laws on American business abroad, Hines (1995) uncovers a substantial decrease in American investment abroad following the ratification of the law. 


\section{EMPIRICS}

\subsection{Data, Specification and Causality}

To assess the impact of FDI on corruption we construct a specification where the latter is explained by FDI inflows, import intensity and per capita income levels, as well as a series of additional controls specified below. Corruption levels are measured in accordance with the International Country Risk Guide indicator (henceforth ICRG), which covers the 1980-94 time period. ${ }^{8}$ All variables are computed as five-year averages, covering the $1980-84$ to $1990-94$ period. ${ }^{9}$ GDP per capita is an important control since per capita income is closely associated with the existence of efficient and transparent institutions. ${ }^{10}$ In our sample, the simple correlation between per capita GDP and corruption levels is -0.71 .

In addition to openness and income per capita, we consider six other determinants of corruption, as suggested by the literature. They are:

- Ethno-linguistic fractionalization: the likelihood that two citizens in a given country belong to a different ethnic or linguistic group. ${ }^{11}$

- $\quad$ Oil exporter status: signals heavy reliance on natural resources; economies which are highly dependent on production and exports of primary goods may be especially vulnerable to corruption as natural resources are geographically immobile and their fruitful exploitation cannot bypass the cooperation of local governments. ${ }^{12}$

\footnotetext{
${ }^{8}$ Previous papers have tended to rely on simple cross-sections. In all specifications we add period dummies that are likely to capture the change in corruption over time due to other omitted factors.

9 See Appendix 1 on data sources and definitions.

${ }^{10}$ On the one hand, good institutions may be a normal good so that higher income per capita leads to higher public demand for institutions; good institutions are more "affordable" in highincome countries where human and physical capital are more widely available. Neeman et al. (2003) consider a neoclassical growth model where corruption is endogenous and negatively correlated with wealth in equilibrium.

11 The degree of a country's ethnic and linguistic heterogeneity has been shown by Mauro (1995) to be relevant in explaining corruption. Shleifer and Vishny (1993) also suggest that ethno-linguistic diversity leads to a more erratic and, thus, more harmful kind of corruption. In his review of the causes of corruption, Tanzi (1993) suggests that in developing countries, where non-economic ties are strong, government officials tend to benefit their next of kin and ethnic group.

12 Leite and Weidmann (1999) present a model where economies abundant in natural resources are prone to display higher levels of corruption. They find that higher levels of natural resources are positively related to higher levels of corruption. Sachs and Warner (1995) have shown that natural resource economies grow more slowly, and suggest this is due in part to a lower efficiency of government. See also Tornell and Lane (1998), who develop a commonpool theoretical model for a country relying on undiversified commodity exports. An increase in the price of that commodity leads to a fight for public revenues between groups, resulting in overspending. This so-called "voracity" effect of price increases on commodity exporters is likely to foster government corruption.
} 
- Government expenditures: Larger involvement of the public sector in the economy is likely to increase the opportunities for corruption. ${ }^{13}$

- Ever a Colony: indicates whether the country achieved independence from a former colonizer after 1825 . Former colonies have been considered less likely to have developed efficient and transparent local institutions.

- Population: controls for the size of the country, as several recent papers suggest a relationship between population and government efficiency. ${ }^{14}$

- Political Rights: The level of rights that are guaranteed by a political system can also be associated with corruption as some of the characteristics of democratic political systems -such as free association, free press and regular and open electoral contests- can increase the likelihood of exposing corrupt activities.

There is an abundant literature on the effects of corruption on openness, particularly on how higher corruption leads to lower levels of foreign direct investment. In this paper we are interested in the opposite direction of causality: how does a higher degree of country openness affect the level of corruption in an economy. Our objective is to find exogenous variables that affect openness but are not affected by individual country characteristics such as corruption.

For each openness indicator, FDI and imports, we build four new variables capturing its exogenous component: ${ }^{15}$ first we compute, for each country in the sample, the inverse of the bilateral distance to each of the 20 largest countries in $1990,{ }^{16}$ and dummy variables indicating whether it shares a land border, an official language or one of the major religions with each of those same 20 economies: ${ }^{17}$ we then take the constant US dollar value of foreign direct investment outflows (or

\footnotetext{
${ }^{13}$ Tanzi (1998) presents a general argument for the relationship between fiscal policy variables and corruption.

${ }^{14}$ The quality of public services may also change with the country size: Fisman and Gatti (2002) and Treisman (1999) present evidence that larger states with lower degrees of decentralization are more corrupt. Knack and Azfar (2003) contest this finding, suggesting it may be the result of sample selection bias since most corruption indices are collected to guide international investors, which are interested in large markets, i.e. countries which are large or, if small, offer a high quality of government (such as Singapore and Hong Kong). Knack and Azfar (2003) argue that per capita rents to be extracted by corrupt customs officials are larger in small countries, so there is greater incentive for corruption. And customs officials, as the authors point out, have been shown by some studies to be the most corrupt among public officials.

${ }^{15}$ Appendix 2 provides a detailed explanation of the creation of the instruments for a country's inflows of foreign direct investment and imports.

16 According to Gross Domestic Product in 1990, the 20 largest economies are: Argentina, Australia, Brazil, Canada, China, France, Germany, India, Indonesia, Iran, Italy, Japan, Korea, Mexico, Netherlands, Poland, Spain, Turkey, United Kingdom and United States.

17 This approach is consistent with the empirical studies based on the gravity equation, which found that geographical proximity, contiguity, common language and land border have exceptional power to explain bilateral trade flows. See, for instance, Frankel et al. (1997). In the case of FDI, Wei (2000a) shows that common linguistic ties and geographical proximity strongly and positively affect foreign direct investment flows.
} 
export flows) for the 20 largest economies and weigh them by the bilateral proximity indicators above $;^{18}$ for each country in the sample we obtain an exogenous indicator of openness (FDI or trade related) as the summation of the product of outflows and bilateral proximity variables. Our expectation is that this instrument captures the fact that, as outflows increase in one of the 20 largest economies, the corresponding inflow for countries that are closest to them -geographically and/or culturally-also increases. In the first stage regressions we explain country FDI inflows (or import flows) using as regressors the total FDI outflows (or export flows) from large countries. ${ }^{19}$

\subsection{Empirical Results}

Table 1 presents summary statistics for the openness indicators, their fitted values, as well as income per capita and corruption indices. As to the openness indicators, we present statistics for their actual and instrumented values. FDI inflows range between 0 and 15 percent of GDP while import intensity has a much wider range of variation. The ICRG corruption index ranges between 0 (lowest corruption level) and 10 (highest). The simple correlation coefficients for the main variables show that higher levels of corruption are associated with a lower share of FDI inflows, lower import intensity and lower income per capita (a coefficient of $-0.33,-0.12$ and -0.71 , respectively). The negative correlation is stronger for FDI than for import intensity, suggesting the importance of this channel for understanding corruption.

TABLE 1

SUMMARY STATISTICS

\begin{tabular}{lcccrr}
\hline Variable & Obs. & Mean & $\begin{array}{c}\text { Standard } \\
\text { deviation }\end{array}$ & Minimum & Min. \\
\hline $\begin{array}{l}\text { Foreign direct investment } \\
\quad \text { Instrumented) }\end{array}$ & 287 & 1.38 & 2.02 & 0 & 14.97 \\
Imports & 328 & 1.44 & 0.90 & 0.64 & 7.13 \\
$\quad$ Instrumented) & 308 & 35.92 & 24.82 & 2.76 & 199.48 \\
Log per capita GDP & 328 & 40.08 & 8.57 & 0.91 & 72.29 \\
Corruption Index & 308 & 8.05 & 1.06 & 5.70 & 10.37 \\
\hline
\end{tabular}

\footnotetext{
18 Religious and linguistic proximity as well as common land border deliver the weights 1 and 0 , whereas bilateral distance provides a continuous weight that decreases as bilateral distance increases.

19 As can be verified in Appendix 2, the first-stage regression of the openness indicators on the instruments finds that most instruments are significant and have the expected sign. Moreover, they explain an important fraction of the total variation of FDI or imports. We also present results for the regression of the residual of the basic corruption specification on the original instruments and find that none is significant, suggesting that the instruments used affect corruption only through their effect on openness.
} 
Table 2 presents ordinary least squares (OLS) and instrumental variable (IV) estimates of the determinants of corruption as represented by an indicator of openness -FDI inflows or import intensity- and per capita GDP ${ }^{20}$ The results are revealing. Neither actual FDI nor import intensity are significantly associated with the level of corruption, but when we instrument these openness indicators, FDI is shown to be strongly and negatively associated with corruption. The size of the coefficient on FDI indicates that an increase in foreign investment inflows of 1 percent of GDP decreases corruption by 0.27 in a scale of 1 to 10 when the extra controls are used. If we consider the standard deviations of FDI and per capita GDP reported in Table 1, the standardized impact of FDI and per capita GDP are of the same order of magnitude. As far as the explanatory power of the regression, we find that openness to FDI and income per capita alone explain a substantial share of the cross-country variation in corruption.

TABLE 2

FOREIGN DIRECT INVESTMENT, IMPORTS AND CORRUPTION DEPENDENT VARIABLE: LEVEL OF CORRUPTION ORDINARY LEAST SQUARES AND INSTRUMENTAL VARIABLE ESTIMATES

\begin{tabular}{lccccccccc}
\hline Estimation method & \multicolumn{2}{c}{ OLS } & \multicolumn{2}{c}{ IV } & \multicolumn{2}{c}{ OLS } & \multicolumn{2}{c}{ IV } \\
\hline FDI openness & -0.05 & -0.02 & $-0.98^{* *}$ & $-0.27 * *$ & - & - & - & - \\
& $(-0,60)$ & $(-0.32)$ & $(-3.14)$ & $(-1.99)$ & & & & \\
Trade Openness & - & - & - & - & 0.006 & 0.008 & 0.02 & -0.07 \\
& & & & & $(1.39)$ & $(1.69)$ & $(0.92)$ & $(-0.23)$ \\
Per capita GDP & $-0.89 * *$ & $-0.92^{* *}$ & -0.26 & $-0.67 * *$ & $-0.92^{* *}$ & $-0.92^{* *}$ & $-0.92^{* *}$ & $-1,56^{* *}$ \\
& $(-9.42)$ & $(-6.43)$ & $(-1.08)$ & $(-3.75)$ & $(-11.55)$ & $(-7.49)$ & $(-11.46)$ & $(-7,05)$ \\
\hline Year dummies & Yes & Yes & Yes & Yes & Yes & Yes & Yes & Yes \\
Additional controls & No & Yes & No & Yes & No & Yes & No & Yes \\
R2 & 0.39 & 0.56 & 0.46 & 0.52 & 0.39 & 0.59 & 0.36 & 0.54 \\
Number of observations & 261 & 240 & 261 & 240 & 261 & 240 & 261 & 240 \\
\hline
\end{tabular}

Note: t-statistics (in parenthesis) are reported below coefficient estimate using heteroskedasticityconsistent standard errors.

** indicates significant at the $5 \%$ level or above.

In Table 3 we estimate the impact of instrumented FDI on corruption after controlling for per capita GDP and trade intensity. We then add, in succession, the additional controls mentioned above: Ethno-linguistic fractionalization, Ever a Colony, Oil Exporter, Government Expenditure, Population and Political Rights. The coefficient on instrumented FDI inflows is negative and significant throughout,

\footnotetext{
20 We always include time dummies and, alternatively, the six control variables identified above. t-statistics are computed using White heteroskedasticity-consistent standard errors. We have also excluded outliers in instrumented FDI and import intensity using the method presented in Hadi and Simonoff (1993).
} 
so that an increase in FDI inflows of 1 percent of GDP decreases corruption by 0.31 points in a 0 to 10 scale. This is quite substantial and probably denotes an effect that is stronger than the association between per capita GDP and corruption. Interestingly, after FDI inflows are considered, we do not find evidence that import intensity per se decreases corruption. ${ }^{21}$ As to the additional controls themselves, oil-exporting countries have a corruption index around 1.09 times higher than other countries and this difference is robust and highly significant, confirming previous results in the literature. An increase in the share of government expenditures in GDP is associated with less corruption and a country which was a colony after 1825 does indeed experience higher corruption.

TABLE 3

FOREIGN INVESTMENT, TRADE AND CORRUPTION

DEPENDENT VARIABLE: LEVEL OF CORRUPTION INSTRUMENTAL VARIABLE ESTIMATES

\begin{tabular}{|c|c|c|c|c|c|c|c|}
\hline & (1) & (2) & (3) & (4) & (5) & (6) & (7) \\
\hline FDI openness & $\begin{array}{l}-1.11^{* *} \\
(-3.28)\end{array}$ & $\begin{array}{c}-0.87 * * \\
(-3.61)\end{array}$ & $\begin{array}{c}-0.67 * * \\
(-3.35)\end{array}$ & $\begin{array}{c}-0.45^{* *} \\
(-2.56)\end{array}$ & $\begin{array}{r}-0.37 * * \\
(-2.37)\end{array}$ & $\begin{array}{c}-0.35^{* *} \\
(-2.28)\end{array}$ & $\begin{array}{l}-0.31 * * \\
(-1.99)\end{array}$ \\
\hline Trade openness & $\begin{array}{c}0.03 * * \\
(3.13)\end{array}$ & $\begin{array}{c}0.02 * * \\
(2.53)\end{array}$ & $\begin{array}{c}0.02 * * \\
(2.51)\end{array}$ & $\begin{array}{c}0.01 \\
(1.58)\end{array}$ & $\begin{array}{l}0.02 * * \\
(2.35)\end{array}$ & $\begin{array}{l}0.02 * * \\
(2.38)\end{array}$ & $\begin{array}{l}0.01 * * \\
(2.30)\end{array}$ \\
\hline Per capita GDP & $\begin{array}{c}-0.17 \\
(-0.67)\end{array}$ & $\begin{array}{c}-0.19 \\
(-0.77)\end{array}$ & $\begin{array}{c}-0.45^{* *} \\
(-2.05)\end{array}$ & $\begin{array}{c}-0.48 * * \\
(-2.45)\end{array}$ & $\begin{array}{r}-0.70 * * \\
(-3.80)\end{array}$ & $\begin{array}{c}-0.72 * * \\
(-3.82)\end{array}$ & $\begin{array}{c}-0.67 * * \\
(-3.70)\end{array}$ \\
\hline $\begin{array}{l}\text { Ethnolinguistic } \\
\text { Fractionalization }\end{array}$ & & $\begin{array}{l}0.009 \\
(1.84)\end{array}$ & $\begin{array}{l}0.004 \\
(0.92)\end{array}$ & $\begin{array}{l}0.001 \\
(0.28)\end{array}$ & $\begin{array}{l}0.001 \\
(0.13)\end{array}$ & $\begin{array}{l}0.0001 \\
(0.03)\end{array}$ & $\begin{array}{l}-0.001 \\
(-0.26)\end{array}$ \\
\hline Oil exporter & & & $\begin{array}{l}1.34 * * \\
(4.04)\end{array}$ & $\begin{array}{l}1.29 * * \\
(4.67)\end{array}$ & $\begin{array}{l}1.19 * * \\
(4.59)\end{array}$ & $\begin{array}{l}1.19 * * \\
(4.63)\end{array}$ & $\begin{array}{l}1.09 * * \\
(4.19)\end{array}$ \\
\hline Ever a colony & & & & $\begin{array}{c}0.74 * * \\
(3.72)\end{array}$ & $\begin{array}{l}0.76^{* * *} \\
(4.18)\end{array}$ & $\begin{array}{l}0.76^{* *} \\
(4.22)\end{array}$ & $\begin{array}{l}0.75 * * \\
(4.20)\end{array}$ \\
\hline $\begin{array}{l}\text { Government } \\
\text { Expenditures }\end{array}$ & & & & & $\begin{array}{r}-5.08 * * \\
(-3.44)\end{array}$ & $\begin{array}{c}-5.11^{* * *} \\
(-3.47)\end{array}$ & $\begin{array}{l}-5.31^{* *} \\
(-3.64)\end{array}$ \\
\hline Population & & & & & & $\begin{array}{c}0.35 \\
(0.55)\end{array}$ & $\begin{array}{c}0.62 \\
(0.98)\end{array}$ \\
\hline Political rights & & & & & & & $\begin{array}{c}-0.44 \\
(-1.48)\end{array}$ \\
\hline Year dummies & Yes & Yes & Yes & Yes & Yes & Yes & Yes \\
\hline $\mathrm{R} 2$ & & 0.10 & 0.30 & 0.44 & 0.51 & 0.51 & 0.53 \\
\hline Number of observations & 261 & 242 & 242 & 242 & 240 & 240 & 240 \\
\hline
\end{tabular}

Note: t-statistics (in parenthesis) are reported below coefficient estimate using heteroskedasticityconsistent standard errors.

** indicates significant at the $5 \%$ level or above.

Another important issue is the role of the level and variability of tariffs on corruption. The natural hypothesis is that higher and more variable trade tariffs are a sign of more discretionary policy choices and, thus, should be associated with

21 This indicates that previous results that find a negative relation between import intensity and corruption may suffer from omitted variable bias and point to the importance of openness to FDI, over and above import openness, to reduce corruption. 
increases in corruption. ${ }^{22}$ We have used three different tariff indicators, available from $\mathrm{Ng}$ (1998) for the 1990s, which are negatively related with openness indicators (trade or FDI) and positively with corruption so that higher level and variability of tariffs are associated with more corruption. We estimated an enlarged specification that included tariff indicators and confirmed the results on trade and FDI: an increase in the level of tariffs tends to increase corruption but the coefficient is statistically significant in only one case. ${ }^{23}$

\section{Conclusions}

This paper makes a first systematic attempt to estimate the effect of openness to foreign direct investment on corruption. It addresses the issue of causality by using a new set of instrumental variables that rely on geographical and cultural proximity to the major originators of FDI outflows.

Some important results arise from the analysis. Foreign direct investment is a robust determinant of corruption: larger FDI inflows decrease national corruption. This result is robust to the inclusion of additional determinants of corruption, the exclusion of outliers and the correction for heteroskedasticity. Second, controlling for import intensity does not change the fundamental result, as the coefficient on FDI remains strongly significant. A third result is the strength of the coefficient on FDI: a 1 percent increase in FDI as a share of output decreases corruption by 0.3 on an index of 1 to 10 . The impact of FDI on corruption is comparable in magnitude to the effect of income per capita.

The literature has previously suggested that higher corruption levels deter FDI inflows. Here we find that the opposite causality also holds: higher FDI inflows are shown to significantly deter corruption.

\footnotetext{
${ }^{22}$ Gatti (2000) has found evidence in support of this argument.

${ }^{23}$ Moreover, once the level of tariffs is controlled for, the variability of tariffs across products does not seem to affect corruption. Both the high correlation of the level and variability of corruption and the small sample size lead us to take these results as merely suggestive. They are available upon request.
} 


\section{REFERENCES}

Ades, A. and R. Di Tella (1999), "Rents, Competition and Corruption",American Economic Review, 89: 982-993.

Barro, R. and J. Lee (1994), "Sources of Economic Growth", Carnegie-RochesterConference-Series-on-Public-Policy; 40: 1-46.

Bhagwati, J. (1982), "Directly Unproductive, Profit-Seeking (DUP) Activities", Journal of Political Economy, 90: 988-1002.

Bhagwati, J. and T. N. Srinivasan (1980), "Revenue Seeking: A Generalization of the Theory of Tariffs", Journal of Political Economy, 88: 1069-1087.

Bliss, C. and R. DiTella (1997), “Does Competition Kill Corruption?", Journal of Political Economy, 105: 1001-1023.

Brock, W. and S. Magee (1978), "The Economics of Special Interest Politics: the Case of the Tariff", American Economic Review Papers and Proceedings, 68: 246250.

Fisman, R., and Gatti (2002), "Decentralization and Corruption: Evidence Across Countries", Journal of Public Economics, 83: 325-345.

Frankel, J., S. Stein and S-J Wei (1997), "Continental Trading Blocs: Are They Natural, or Super-Natural?". In J. Frankel (ed.) The Regionalization of the World Economy, University of Chicago Press, Chicago.

Freedom House (2003), "Freedom House Country Ratings", http://www.freedomhouse.org, Freedom House, New York.

Gatti, R. (2000), "Corruption and Trade Tariffs, or a Case for Uniform Tariffs", World Bank Working Paper $\mathrm{N}^{\circ} 2216$.

Hadi, A. and J. Simonoff (1993), "Procedures for the Identification of Multiple Outliers in Linear Models", Journal-of-the-American-Statistical-Association; 88 (424): 1265-1272.

Helpman, E. (1997), "Politics and Trade Policy”. In Kreps, D. and K. Wallis (eds.), Advances in Economics and Econometrics: Theory and applications: Seventh World Congress. Volume 1. Econometric Society Monographs, no. 26. Cambridge; New York and Melbourne: Cambridge University Press, 1997: 19-45.

Hines, J. (1995), "Forbidden Payment: Foreign Bribery and American Business After 1977”, NBER Working Paper 5266, Cambridge.

International Country Risk Guide (2001). Financial, political and economic risk ratings for 140 countries. PRS Group. http://www.prsgroup.com/icrg/icrg.html

Kaufmann, D. and S-J. Wei (1999), "Does 'Grease Money' Speed Up the Wheels of Commerce?", NBER Working Paper 7093.

Knack, S. and O. Azfar (2003), "Country Size, Trade Intensity and Corruption”. Economics of Governance, 4: 1-18.

Keefer, P. and S. Knack (1995), "Institutions and Economic Performance: Cross-Country Tests Using Alternative Institutional Measures", Economics and Politics, 7, November: 207-227.

Kimberley, A., (ed.) (1997), Corruption and the Global Economy. Institute for International Economics, Washington, DC.

Krueger, A. (1974), "The Political Economy of the Rent Seeking Society", American Economic Review 64, no. 3, June: 291-303.

LaPorta, R., Lopez de Silanes, F., Shleifer, A. And R.Vishny (1999), "The Quality of Government", Journal of Law, Economics, and-Organization; 15: $222-279$. 
Leff, N. (1964), "Economic Development through Bureaucratic Corruption", American Behavioral Scientist: 8-14.

Leite, C. and J. Weidmann (1999), "Does Mother Nature Corrupt? Natural Resources, Corruption and Economic Growth", International Monetary Fund Working Paper, Washington DC.

Mauro, P. (1995), "Corruption and Growth", Quarterly Journal of Economics, 110(3): 681-712

Mauro, P. (1998), "Corruption and the Composition of Government Expenditure", Journal of Public Economics, 69: 263-279.

Neeman, Z., Paserman, D. and A. Simhon (2003), "Corruption and Openness", CEPR Discussion Paper 4057.

Ng, F. and A. Yeats (1998), "Good Governance and Trade Policy: Are They the Keys to Africa's Global Integration and Growth?", World Bank Working Paper, Development Research Group, The World Bank, Washington D.C.

Rose-Ackerman, S. (1975), “The Economics of Corruption”, Journal of Public Economics, 4: $187-203$.

Sachs, J. and A. Warner (1995), "Natural Resource Abundance and Economic Growth", HIID Development Discussion Paper N ${ }^{\circ}$ 517, Harvard University.

Shleifer, A. and R. Vishny (1993), "Corruption", Quarterly Journal of Economics, 108: 599-617.

Tanzi, V. (1994), “Corruption, Governmental Activities and Markets”, IMF Working Paper 94/99, Washington DC.

Tanzi, V. (1998), "Corruption Around the World - Causes, Consequences, Scope, and Cures", IMF Staff Papers, 45: 559-594.

Tanzi, V. And H. Davoodi (1997), "Corruption, Public Investment, and Growth", IMF Working Paper 97/139, Washington DC.

Tornell, A. and P. Lane (1998), "Voracity and Growth", American Economic Review.

Treisman, D. (1999), "Decentralization and Corruption: Why Are Federal States Perceived to be More Corrupt?", Mimeo, UCLA Department of Political Science.

Wei, S-J. (1997), "Why is Corruption So Much More Taxing Than Tax? Arbitrariness Kills", NBER working paper $\mathrm{N}^{\circ} 6255$.

Wei, S-J. (2000a), "How Taxing is Corruption on International Investors?", Review of Economics-and-Statistics; 82(1): 1-11.

Wei, S-J. (2000b), "Natural Openness and Good Government", NBER Working Paper 7765, Cambridge, MA.

World Bank (1998), World Development Indicators. World Bank, Washington DC. 


\section{APPENDIX 1 \\ DATA SOURCES AND SUMMARY STATISTICS}

FDI - Source: World Bank (1998). Definition: Gross inflows of foreign direct investment as a share of the domestic economy's GDP. Unit: Percent.

Import Intensity - Source: World Bank (1998). Definition: Imports as a share of GDP. Unit: Percent.

Tariffs - Source: World Bank (1998) for Tariff 1 and $\mathrm{Ng}$ and Yeats (1998) for Tariff 2 and 3. Definition: Average level and standard deviation of tariffs. Unit: Tariff levels in percent.

Corruption - Source: International Country Risk Guide (2001) and Mauro (1995) for the Business International indicator. Definition: Indicator of corruption as reported by international consultants. Unit: 0 to 6 , with higher values denoting less corruption, converted to a 0 to 10 scale where higher values denote more corruption.

GDPpc-Source: World Bank (1998). Definition: Level Gross Domestic Product per capita at the beginning of the five-year period. Unit: US Dollars PPP.

Fractionalization - Source: LaPorta et al. (1999). Definition: Measures ethnolinguistic fractionalization: the probability that two randomly selected individuals within the country belong to the same religious and ethnic group. Unit:Continuous variable between 0 and 100, with 100 denoting lower fractionalization.

Oil Exporter - Source: Barro and Lee (1994). Definition: Dummy for oil exportingcountries. Unit: Dummy.

Government Expenditures - Source: Barro and Lee (1994). Definition: Share of government expenditures in GDP. Unit: Continuous variable.

Ever a Colony - Source: Barro and Lee (1994). Definition: Countries that were colonies after 1825. Unit: Dummy variable with 1 denoting colony.

Population - Source: Barro and Lee (1994). Definition: Country population. Unit: In millions.

Political Rights - Source: Freedom House (2003). Definition: In the source, it ranges between 1 (best) and 6 (worst). It was recomputed to range between 0 and 1. Unit: Between 0 and 1. 


\section{APPENDIX 2 INSTRUMENTS FOR OPENNESS}

Here we explain the procedure to develop new and more powerful instruments as indicators of a country's openness, measured by imports and foreign direct investment inflows. In the context of the present paper we wanted to find variables that were exogenous and did not affect the degree of corruption directly. We have built four new variables that are likely to affect openness but can at the same time be reasonably seen as totally exogenous to a country's policy choices. The procedure was the following:

1. Select the 20 largest economies by Gross Domestic Product in 1990. The full list includes Argentina, Australia, Brazil, Canada, China, France, Germany, India, Indonesia, Iran, Italy, Japan, South Korea, Mexico, Netherlands, Poland, Spain, Turkey, the United Kingdom and the United States.

2. Compute, for each country pair in the sample to one of 20 largest economies, 4 variables that indicate the geographic and cultural closeness between each country in the sample and each of the 20 largest. The variables are: bilateral distance, a dummy taking the value 1 if the country pair has a common land border, a dummy taking the value 1 if the country pair has the same majority religion and a dummy taking the value 1 if the country pair shares an official language.

3. Take the constant US dollar value of FDI outflows and exports for each of the 20 largest economies, averaged for each five-year period, and multiply them by the dummy variables constructed in 2 . For bilateral distance, multiply the trade and investment flows by the inverse of the distance. The sum in each of the four categories (distance, contiguity, religion and language) constitutes the instrument for the trade and investment openness of each country in the sample.

For example, each country in the sample will have four exogenous variables that will serve as instruments for its degree of trade openness, defined as:

$$
\begin{aligned}
& \text { FDI-DI } \mathrm{i}_{\mathrm{i}}=\sum_{\mathrm{j}=1}^{20 \text { largest }}\left\{\left(\text { Inverse of Bilateral Distance }_{\mathrm{i}, \mathrm{j}}\right) * \text { FDI Outflows }_{\mathrm{j}}\right\} \\
& \text { FDI }-\mathrm{CO}_{\mathrm{i}}=\sum_{\mathrm{j}=1}^{20 \text { largest }}\left\{\text { Contiguous }_{\mathrm{i}, \mathrm{j}} \text { FDI Outflows }{ }_{\mathrm{j}}\right\} \\
& \text { FDI }-\mathrm{RE}_{\mathrm{i}}=\sum_{\mathrm{j}=1}^{20 \text { largest }}\left\{\text { Religion }_{\mathrm{i}, \mathrm{j}} * \text { FDI Outflows }{ }_{\mathrm{j}}\right\} \\
& \text { FDI-LA }{ }_{\mathrm{i}}=\sum_{\mathrm{j}=1}^{\text {20largest }}\left\{\text { Language }_{\mathrm{i}, \mathrm{j}} * \text { FDI Outflows } \mathrm{j}_{\mathrm{j}}\right\}
\end{aligned}
$$


The same four-fold set of variables is built in a similar way using exports of the 20 largest economies. We are left with a group of exogenous variables that capture the export and FDI impulses from the largest economies and weigh them by the geographical and cultural proximity to each of the economies in the sample. These exogenous variables are different for each of the openness indicators. We regressed actual FDI (or import intensity) on the exogenous instruments presented above and the respective t-stats for these first-stage regressions are presented below. We also assessed whether the exogenous instruments had a direct impact on corruption in addition to their impact through openness: the t-stats of the four exogenous instruments on the residual of the corruption equation are also reported below. They confirm that the instruments only affect corruption through openness.

INSTRUMENTS FOR IMPORTS AND FDI FIRST STAGE AND RESIDUAL REGRESSION STATISTICS

\begin{tabular}{lccccc}
\hline & \multicolumn{2}{c}{ Foreign direct investment } & & \multicolumn{2}{c}{ Imports } \\
\cline { 2 - 3 } \cline { 5 - 6 } \cline { 5 - 6 } & First stage & Residuals & & First stage & Residuals \\
\hline Contiguity & -0.71 & 0.53 & & -5.41 & 0.96 \\
Distance & 4.65 & -0.40 & & 0.75 & -0.54 \\
Religion & 3.82 & 0.14 & & 0.59 & -0.84 \\
Language & -1.26 & 0.53 & & 1.99 & -0.32 \\
& & & & & \\
Nr. observations & 338 & 240 & & 338 & 240 \\
R2 & 0.18 & 0.002 & & 0.06 & 0.005 \\
\hline
\end{tabular}

Note: We report t-statistics based on heteroskedastic-consistent standard errors. The first stage regression has FDI/import intensity as the dependent variable whereas the residuals regressions use as dependent variable the difference between actual and predicted corruption. Predicted corruption is computed from the baseline regressions as specified in the last column of Table 3 , and similarly for imports. In the residuals regressions, the dependent variable is the difference between actual and predicted corruption and the right-hand-side variables are the four instrumental variables for FDI (correspondingly for import intensity) and the time dummies. 